Article

\title{
Can Allotment Gardens (AGs) Be Considered an Example of Nature-Based Solutions (NBS) Based on the Use of Historical Green Infrastructure?
}

\author{
Barbara Sowińska-Świerkosz ${ }^{1}$, Malwina Michalik-Śnieżek ${ }^{2, *}$ and Alicja Bieske-Matejak ${ }^{2}$ \\ 1 Department of Hydrobiology and Ecosystems Protections, University of Life Sciences in Lublin, \\ 20-262 Lublin, Poland; barbara.sowinska@wp.pl \\ 2 Department of Grassland and Landscape Shaping, University of Life Sciences in Lublin, \\ 20-950 Lublin, Poland; alu.bieske@wp.pl \\ * Correspondence: malwina.sniezek@up.lublin.pl; Tel.: +48-503-508-961
}

Citation: Sowińska-Świerkosz, B.; Michalik-Snieżek, M.; Bieske-Matejak, A. Can Allotment Gardens (AGs) Be Considered an Example of Nature-Based Solutions (NBS) Based on the Use of Historical Green Infrastructure? Sustainability 2021, 13, 835. https://doi.org/10.3390/ su13020835

Received: 11 December 2020

Accepted: 12 January 2021

Published: 15 January 2021

Publisher's Note: MDPI stays neutral with regard to jurisdictional claims in published maps and institutional affiliations.

Copyright: (c) 2021 by the authors. Licensee MDPI, Basel, Switzerland. This article is an open access article distributed under the terms and conditions of the Creative Commons Attribution (CC BY) license (https:/ / creativecommons.org/licenses/by/ $4.0 /)$.

\begin{abstract}
The term nature-based solutions (NBSs) is understood as a multidisciplinary umbrella concept that includes aspects such as green/blue infrastructure and urban gardens and forests. However, the important question here is what features of ecosystem-based approaches are essential for them to be considered nature-based? This study aims to answer this question by analysing the potential of allotment gardens (AGs) to be considered as NBSs. To do so, the possibilities and obstacles regarding a Polish case study were analysed based on the following six research questions: (1) How do AGs use blue and green infrastructure? (2) What problem(s) do AGs solve today? (3) What kind of benefits do AGs provide? (4) Do AGs possess implementation and management capabilities? (5) Can AGs be treated as economically efficient? (6) What are the advantages of AGs versus other possible solution(s)? With regards to obstacles, the study has identified: institutional barriers, irregular distribution of benefits, and deficiencies in economic efficiency. Nevertheless, AGs together with other historical urban green/blue infrastructure may be regarded as a kind of unsophisticated NBS, the effectiveness of which is limited. These solutions may be created as independent structures or (historical) green/blue infrastructure may be enlarged, fitted out, linked, and improved to implement NBS projects.
\end{abstract}

Keywords: allotment gardens; ecosystem-based solutions; green/blue infrastructure; nature-based solutions; Poland

\section{Introduction}

Nature-based solutions (NBSs) are understood as a multidisciplinary umbrella concept which links social benefits with a notion of "nature". NBSs relate to or overlap with other concepts such as ecological engineering, catchment systems engineering, ecosystem approaches, ecosystem-based adaptation/mitigation, ecosystem services, and natural capital [1]. However, this link with pre-existing concepts has resulted in an ambiguous understanding of the term. Furthermore, quite similar terms such as nature-based infrastructure and engineering with nature [2] had already been introduced before this concept became popular within the HORIZON 2020 programme. Many synonymous and similar terms are used interchangeably with NBS, including green and blue infrastructure, urban green space, urban gardens, urban forests, urban lakes, and canals and fountains [3]. Synonyms are used in reference to review studies [3-6], conceptual papers [1,4,7], and case studies [8].

The European Commission (EC) report [9] referring to NBS actions has stated that "some involve using and enhancing existing natural solutions to challenges, while others are exploring more novel solutions". Thus, the two general kinds of NBSs can be implemented. The first involves using and enhancing existing natural solutions; the second involves 
exploring more novel solutions. Thus, this report recognizes that rather than being limited to modern solutions such as constructed wetlands and green roofs and walls, historical structures also have the potential to be regarded as NBSs. In addition, this report mentions many possible interventions based on historical urban greenery, such as: the protection of urban green spaces, avenues of trees alongside roads, the use of permeable surfaces as well as vegetation, ponds, gardens, and recreational green areas alongside rivers.

Regardless of the type of NBS (historical structure or innovative solution), this notion conceptualizes actions addressing environmental, social, and economic challenges simultaneously by maximizing the benefits provided by nature [9]. NBSs are mostly considered as solutions that provide people and environments with a diverse set of services, and not just as another tool for nature conservation and restoration $[1,10]$. Such an understanding relates to the notion of "strong" sustainability, which does not give priority to the natural capital [11]. As a result, generally three main pillars of these solutions are identified: (1) environmental, (2) social, and (3) economic [6,12,13].

\subsection{Environmental Pillar}

Most of the projects dealing with the environmental pillar aim at conservation, restoration, and cultivation goals, with special consideration given to one or more of the following aspects: (1) biodiversity and wildlife [6]; (2) water regulation and quality enhancement [14]; and (3) air quality control and climate regulation [4]. Nature-based solutions include protection, restoration, rehabilitation, and re-naturalizing actions which are taken to: (1) preserve and strengthen the existing habitats or (2) create new ones. Their implementation showed a multitude of positive effects of NBSs on the environment including: enhancing the natural capital, promoting biodiversity, creating new habitats, decreasing the risk of flooding, mitigating water runoff, enhancing water resilience, increasing water retention and infiltration, better management of surface run-off, drought prevention, contribution to climate change adaptations and carbon sequestration, emission reduction, UHI mitigation, increasing air quality, increasing ES provisioning, creating shade, removing pollutants, and reducing noise $[3,6,10]$. It was also determined that NBSs provide a multitude of provisioning services such as fresh food, wood, and water [5,7]. A review conducted by Xie and Bulkeley [6] showed that current NBS projects place emphasis on ecosystem diversity, the improvement of ecological functioning, and habitat protection and enhancement. Less attention is given to species and genetic diversity, promotion of native species, and NBSs' contribution to soil protection and amelioration. Among the quantitative indices measuring the planned and real effects of the solutions used are the following: the number of trees planted and the amount of green/blue areas to be created and restored. Besides, there is a number of indices showing the ratio of the area covered by greenery and open water, such as the Berlin Biotope Area Factor, the Poland Ratio of Biologically Active Area, or the Seattle Green Factor [5], and indices based on the NDVI (Normalized Difference Vegetation Index) and tree canopy measurements [4]. Direct (in-situ) and surrogate (land cover structure, connectivity, and fragmentation metrics) biodiversity measures are also commonly applied to demonstrate the effect of the variability of life on the composition, structure, and functioning of landscape [15]; with special consideration given to the conservation of rare and endangered species, as well as the impact of native, non-native, and invasive species. These indicators, however, are aimed at the simple measurement of ecological effects and do not take into account social and economic factors being equally treated in the NBS approach.

\subsection{Social Pillar}

Previous research on the social issues connected to the topic of NBSs in urban regeneration were related to three main aspects: (1) social benefits and costs [12,13] including environmental justice [16]; (2) public participation in NBS projects including challenges and opportunities of the participants; and (3) social perception and preferences for green solutions [3]. A range of qualitative, quantitative, and mixed methods, both monetary and non-monetary, were used to assess the impact on NBSs on social dimensions. They include: 
Q methods, narrative analysis, fuzzy cognitive mapping, PPGIS, 3D visualizations, E-tools, questionnaires and surveys, workshops and meetings, multi-criteria analysis, cost-benefit analyses, and the use of social media [3,17]. The results of the research showed that NBSs have many positive effects on society including benefits such as: the improvement of mental and physical health, social cohesion, community support, place attractiveness, and the creation of green jobs $[4,7,13]$. It promotes outdoor activities, creating new recreational areas and sports facilities, re-connecting people with nature, improving their involvement in restoration actions, and raising social awareness [9]. On the other hand, there are social costs and downsides resulting from NBS implementation, including negative qualities and unpleasant experiences. These include: increased exposure to allergenic pollen, increased numbers of mosquitos, inequalities in the access to NBSs, increase in prices of both land and rent, growth of crime and vandalism rates, and dirtiness, e.g., leaves in autumn $[1,3,18]$. The issue of downsides, however, is much less often analysed than the issue of benefits. Moreover, lots of perceived problems were detected in relation to NBSs such as: lack of knowledge and awareness, lack of evidence of successful solutions, lack of political support, bureaucracy, inadequacy of financial resources, and institutional fragmentation [3]. Among socio-economic factors related to NBSs, the age factor was extensively analysed [4], the gender issues, however, have not been so far thoroughly investigated in relation to the NBS term. Existing examples relate only to the selected topics such as perceived values [19] and health benefits [20]. Research conducted so far has related mainly to the gender nature of ecosystem services (ES) [21] and showed that the gender impact is not universal in nature and strongly differs across geographic and temporal scales [18]. Generally, it was revealed that women have a tendency to rate the benefits of green and blue areas higher [22,23] and they appreciate the visual values more $[19,24]$. Regarding the social pillar, recent studies suggested that more attention should be given to the inclusion of local and indigenous knowledge in the process of designation, implementation, and management of NBSs. The participation of citizens and stakeholders in NBSs is a key to the success of these solutions, thus co-creation and co-design with different actors should be a starting point in any NBS project [7].

\subsection{Economic Pillar}

NBSs are considered to contribute to substantially more complex, holistic, and interdisciplinary understandings and applications of economic issues into environmental aspects, in contrast to earlier applications of the term which often focused on economic valuations of "natural capital" [25]. The economic efficiency of the solutions is especially important in the case of the urban environment, posing both benefits and risks for the quality of life. NBSs have a potential to be included in the process of urban planning, as aspects are related to sustainable economic growth and fair distribution of income. Potentially high economic efficiencies of NBSs resulted from the promotion of a "transition" from a resource-intensive growth model towards a more resource-efficient model $[5,9,26,27]$. This efficiency, in relation to the NBSs, means that the cost of the solution implementation, maintenance, or transformation should not exceed the potential environmental and social benefits [9]. It includes the costs of planting, irrigation, water management, energy, and repairs of engineering infrastructure.

The economic benefits of NBSs are strongly connected to the environmental and social pillars. Regarding the first aspect, to be cost- and resource-efficient, artificial irrigation should not consume drinking water resources, but should use rainwater or treated sewage water instead. Furthermore, smart irrigation control techniques should be implemented to avoid overwatering or waterlogging, which can cause plants to die [5]. Renewable sources of energy are preferred over non-renewable ones: ideally NBSs should be self-sufficient in terms of water and energy. Of course, urban green infrastructure always generates some maintenance costs deriving from the changeable nature of greenery (re-planting because of diseases and physical damage, cleaning the leaves, mowing and trimming) as well as the need to maintain high aesthetic values. These costs, however, may be reduced through the 
selection of high-quality plants, the use of smart irrigation systems, and the establishment of plant management [5].

Economic benefits regarding the social pillar were inter alia proven in relation to the following aspects: creation of green jobs, lower costs of medical care, and a source of cheap fresh products $[4,7,9,13]$. NBSs are a source of green jobs thus they create decent employment opportunities for working in agricultural, manufacturing, research and development, administrative, and service activities that contribute considerably to preserving or restoring environmental quality. Both types of NBSs, innovative and based on traditional solutions, possess a strong employment potential for specialists in different fields, such as biologists, engineers, and planners, as well as gardeners and conservators of green areas. The improvement of mental and physical health is an indirect factor lowering the cost of treatment, both in terms of expenses of individual households and state economies [28].

\section{The Aim of the Paper}

The general aim of this paper is to analyse the potential of allotment gardens (AGs) as an effective NBS utilizing historical urban green structures. To do so, the possibilities and obstacles regarding a Polish case study were analysed based on the six questions referring to the following key features of NBSs: (1) the use of blue and green infrastructure; (2) the effectiveness of problems solving; (3) the provision of multiple benefits; (4) the possession of implementation and management capabilities; (5) economic efficiency; and (6) AGs' advantages and disadvantages versus other possible solution(s).

The reason for both analysing the possibilities of AGs to be a part of NBSs and for taking this research is the fact that AGs, and generally speaking historical urban green/blue infrastructure, should be considered, according to the European Commission Report [9], as actions that are parallel to innovative approaches based on the application of new technologies. So far, however, little research has been done on this globally, and the Polish case study has not yet been analysed. The combination of AGs into the NBS framework, however, is important for many reasons. First of all, gardens and parks were proven to be a good example of integrated NBSs, since they can improve human health and wellbeing, biodiversity, and also reduce flood and drought risk and store carbon [9]. Besides, according to the European Commission Report [9], actions regarding NBSs should be built on existing knowledge by learning from solutions, methods, databases, and networks already used. The long history of Polish AGs provides a better source of knowledge, including the advantages, limitations, and impacts on social and environmental pillars of this solution, than other green solutions. Besides, knowledge gaps can be targets for future research. Thus, scientists and planners can use these historical green structures to "learn by comparing" [9] (p. 69) and so combine or improve the existing structures with new solutions. Generally speaking, all types of existing city green and blue networks can facilitate the replication of demonstration projects and up-scale the capacity for interventions. Last but not least, historical urban green/blue infrastructures such as Polish AGs excel as novel solutions in one aspect: NBSs are likely to be better understood in the long-run, referring to all spheres of potential outputs, trade-offs, and synergies [4]. This fact is very important, taking into account that Polish AGs are rooted in local traditions constituting a historically continuous element of space in a rapidly changing environment. Thus, the possibility to analyse their performance in the long-run will bring potential benefits to the state of knowledge on the nature-based solutions.

\section{Materials and Methods}

\subsection{Case Study Characteristic: Polish Allotment Gardens (AGs)}

AGs are plots of land made available for individual, non-commercial gardening or for growing food plants. They have been present in many European countries since the 19th century, including Germany, Denmark, Finland, Netherlands, Norway, the UK, and Poland [29]. Today, they can be also found in countries such as Malta, the Philippines, and Portugal, where they have been created to encourage people living in urban areas 
to take up organic farming. In Poland, the first AGs were created at the end of the 19th century and their number increased gradually throughout the 20th century. The particular reasons behind their creation varied depending on the location, time of development, and organizational conditions, but what was universal were unfavourable socioeconomic factors [28,30,31]. The food provision and economic functions of AGs have been of greatest importance for many years. In most countries including Poland, however, the shift from food production and economic use to recreational use has taken place gradually [32]. In most cases, native edible plants have been replaced by those regarded as more visually attractive or ones that are locally "popular" at a given time. This shift is well documented and quantified. For example, years of study conducted by Duś [28] showed that around 1980, only every fifth gardener planted ornamental trees, whereas now there is an average of two exotic trees per allotment. The result is that nowadays the most characteristic element of AGs is a more or less carefully maintained lawn with decorative plants. Analogously, Roman Szkup [33] reports that in the 1980s, ornamental plants occupied about 5-10\% of the area of the garden, whereas currently this share ranges from 3 to even $70 \%$ (standard plot has $300 \mathrm{~m}^{2}$ ).

Nowadays, allotment gardens are very characteristic elements of the Polish urban landscape covering about 43,000 hectares of urban space. They occupy a substantial area of most of the large city structures, e.g., approx. $2.2 \%$ of the area of the Katowice conurbation [28], 3.1\% of Poznan area [34], and 2.92\% of the entire Tri-City [35]. They are usually scattered across the city structure. It was estimated that currently in Warsaw and the neighbouring communes there are about 170 family allotment gardens with 30,000 individual plots [29]. They take the form of fenced fragments of land bordering other types of land development (Figure 1), among which the highest share consists of residential (14.8\%), service and communication land cover forms (35.6\%), and agricultural land (23.8\%) [33].

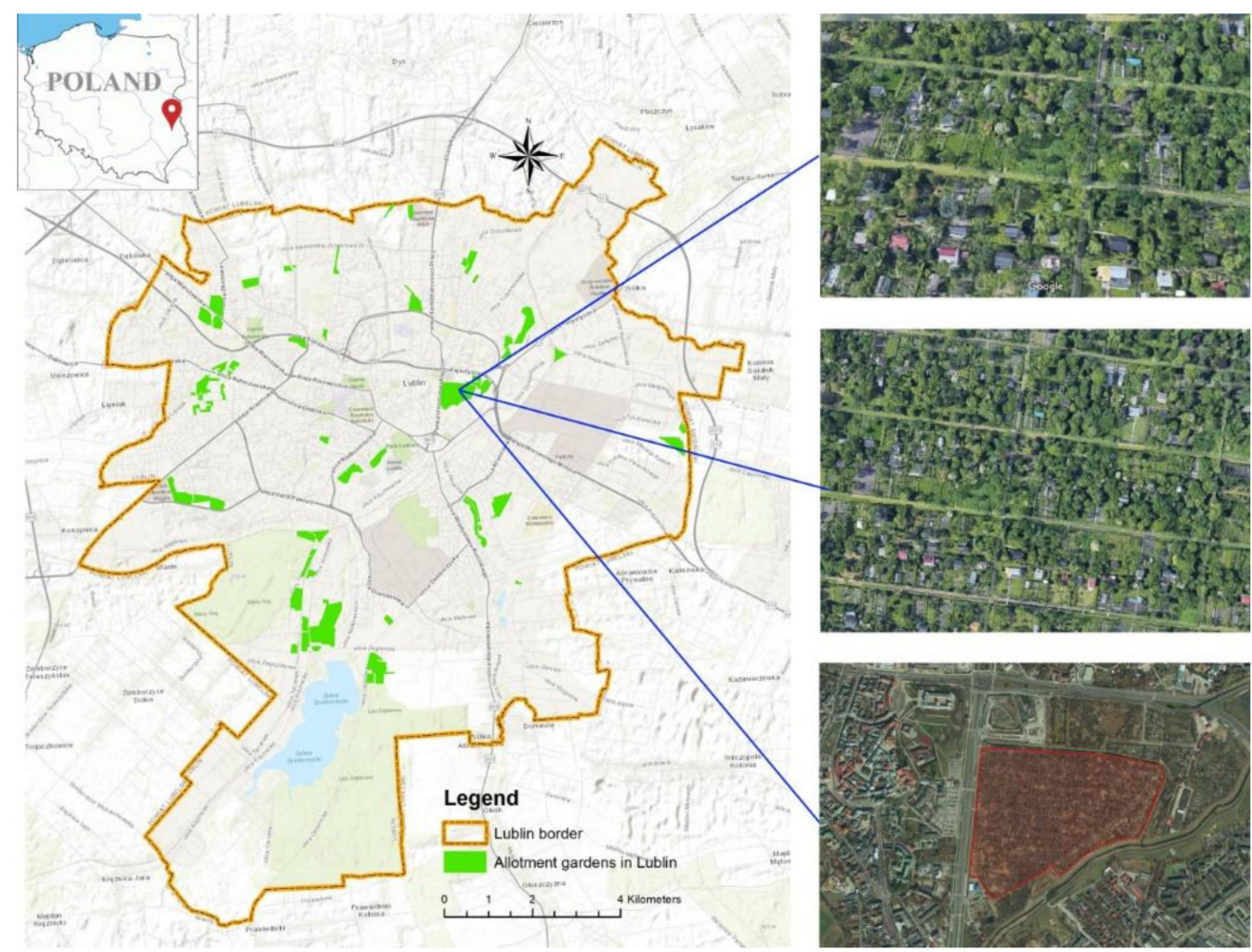

Figure 1. Allotment gardens located within the city limits of Lublin and a view of the "Podzamcze" AGs in the city centre.

Such an arrangement of AGs results in the distance between the garden and the users' house being less than $1 \mathrm{~km}$, which coincides with a 15 min walking range [36]. Ninety 
percent of these family gardens are located within a range of cities, whether in the city centre or on the outskirts, contributing to the density of urban green infrastructure. Individual gardens usually have different forms of cabins, with an average area of $15.5 \mathrm{~m}^{2}$ [28]. Some of them are equipped with electricity and water.

AGs in Poland are used by people of all ages, with different social statuses and passions: for children, they offer places to play; for the unemployed, they give a feeling of usefulness; for the elderly and the disabled, they provide an opportunity to meet others; for nature lovers they offer proximity to nature; and for amateur gardeners, they are places of experimentation [29,31].

The main legal advisory here is the Polish Garden Association, which runs nearly 5000 family AGs comprising of almost 1000 plots with a total area of 44 ha; about 5 million Poles benefit from these areas [29]. A legal definition of an AG was introduced in 2013 by the Act on Allotment Gardens, as "a separate area, intended for AGs, consisting of individual plots and a common area, used for a common use by gardeners, equipped with garden infrastructure".

\subsection{Method of Research}

The first stage of research aimed to identify the key features of NBSs on the basis of the non-systematic review of papers dealing with this concept $[9,10,37-39]$. As a result, it was possible to indicate six features considered crucial for any solution to be viewed as a nature-based solution according to the concept presented in the European Commission Report [9].

Secondly, based on these key features, questions referring to the assessment of any solution to be considered as NBSs were formulated.

The third stage aimed to analyse the potential of Polish AGs to be considered as effective NBSs based on the use of these historical urban green structures. The main data source used in this stage were the results of the systematic review of literature on Polish AGs. The search was based on the Scopus database. Only English and Polish papers were considered. As the search criteria, the following entries were looked into: "allotment gardens" OR "commune gardens" OR "family gardens" AND "Poland" in the title, abstract, and keywords (November 2020) giving a total set of 98 results. The papers were sorted according to their relevance and then screened for data on the six questions formulated in the previous stage of the study. Most of the papers, however, were excluded from the research due to the following reasons: the focused solely on the analysis of metals in soils and soil contamination (25 papers); they focused on AGs as one of the types of land cover (LC) without the deeper understanding of their performance (17 papers); or they were out of the subject framework (44 papers) as they mostly referred to other types of Polish gardens. As a result, only 12 papers fulfilled the screening requirements. This is why an additional four key papers written in Polish were also analysed. As a result, 16 papers formed a basis for the analysis of the potential of Polish AGs to be considered as effective NBSs based on the use of these historical urban green structures (Table 1). 


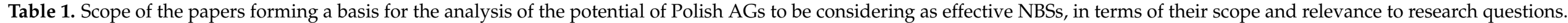

\begin{tabular}{|c|c|c|c|c|c|c|c|c|}
\hline \multirow[b]{2}{*}{ Papers } & \multirow[b]{2}{*}{$\begin{array}{l}\text { Thematic Scope } \\
\text { of Paper }\end{array}$} & \multirow[b]{2}{*}{$\begin{array}{l}\text { Spatial Scope } \\
\text { of Paper }\end{array}$} & \multicolumn{6}{|c|}{ Research Questions } \\
\hline & & & $\begin{array}{l}\text { How do AGs Use } \\
\text { Blue and Green } \\
\text { Infrastructure? }\end{array}$ & $\begin{array}{c}\text { What } \\
\text { Problem(s) do } \\
\text { AGs Solve } \\
\text { Today? }\end{array}$ & $\begin{array}{l}\text { What Kind of } \\
\text { Benefits do AGs } \\
\text { Provide? }\end{array}$ & $\begin{array}{l}\text { Do AGs Possess } \\
\text { Implementation } \\
\text { and Management } \\
\text { Capabilities? }\end{array}$ & $\begin{array}{l}\text { Can AGs be } \\
\text { Treated as } \\
\text { Economically } \\
\text { Efficient? }\end{array}$ & $\begin{array}{c}\text { What are the } \\
\text { Advantages of AGs } \\
\text { versus Other } \\
\text { Possible } \\
\text { Solution(s)? }\end{array}$ \\
\hline \multicolumn{9}{|c|}{ English Language Papers } \\
\hline $\begin{array}{c}\text { Bartłomiejski \& } \\
\text { Kowalewski } 2019 \text { [40] }\end{array}$ & $\begin{array}{l}\text { AGs contribution to } \\
\text { the "slow city" concept }\end{array}$ & $\begin{array}{l}\text { The five largest Polish } \\
\text { cities: Warszawa, } \\
\text { Kraków, } \\
\text { Szczecin, Łódź, } \\
\text { Wrocław }\end{array}$ & & & $\sqrt{ }$ & $\sqrt{ }$ & $\sqrt{ }$ & \\
\hline Borysiak et al. 2016 [41] & $\begin{array}{c}\text { Floral biodiversity } \\
\text { of AGs }\end{array}$ & $\begin{array}{l}\text { The city of Poznań } \\
\text { (Poland) }\end{array}$ & $\sqrt{ }$ & & & & & \\
\hline Duś 2014 [28] & $\begin{array}{l}\text { Recreational use and } \\
\text { health functions }\end{array}$ & $\begin{array}{l}\text { Katowice conurbation } \\
\text { (Poland) }\end{array}$ & $\sqrt{ }$ & & $\sqrt{ }$ & & & \\
\hline $\begin{array}{c}\text { Jasionkowski and } \\
\text { Lewandowska-Czarnecka } \\
2016[42]\end{array}$ & $\begin{array}{l}\text { Possibilities of food } \\
\text { production }\end{array}$ & Polish cities in general & & $\sqrt{ }$ & & & & \\
\hline Kabala et al. 2009 [43] & $\begin{array}{l}\text { Concentration of heavy } \\
\text { metals in soils of AGs }\end{array}$ & $\begin{array}{l}\text { The city of Wroclaw } \\
\text { (Poland) }\end{array}$ & & & $\sqrt{ }$ & & & \\
\hline Moskalonek et al. 2020 [35] & $\begin{array}{l}\text { Changes in the } \\
\text { function of AGs in } \\
\text { attractive location }\end{array}$ & Tri-City (Poland) & & & $\sqrt{ }$ & $\sqrt{ }$ & & \\
\hline $\begin{array}{c}\text { Trembecka, \& } \\
\text { Kwartnik-Pruc } 2018 \text { [44] }\end{array}$ & $\begin{array}{l}\text { Spatial distribution of } \\
\text { AGs and their } \\
\text { legal status }\end{array}$ & $\begin{array}{l}\text { The city of Cracow } \\
\text { (Poland) }\end{array}$ & & & $\sqrt{ }$ & $\sqrt{ }$ & & $\sqrt{ }$ \\
\hline $\begin{array}{l}\text { Pawlikowska-Piechotka } \\
2012 \text { [45] }\end{array}$ & $\begin{array}{c}\text { Policy and } \\
\text { management of AGs }\end{array}$ & $\begin{array}{l}\text { The city of Warsaw } \\
\text { (Poland) }\end{array}$ & & $\sqrt{ }$ & $\sqrt{ }$ & $\sqrt{ }$ & & \\
\hline $\begin{array}{c}\text { Poniży \& Stachura } \\
2017 \text { [34] }\end{array}$ & $\begin{array}{l}\text { Urban spatial policy } \\
\text { towards allotment } \\
\text { gardening }\end{array}$ & $\begin{array}{l}\text { The city of Poznań } \\
\text { (Poland) }\end{array}$ & & & & $\sqrt{ }$ & & \\
\hline Rowiński et al. 2017 [46] & $\begin{array}{l}\text { AGs as recreation } \\
\text { places for older people }\end{array}$ & Polish cities in general & & & $\sqrt{ }$ & & & \\
\hline Speak et al. 2015 [47] & $\begin{array}{l}\text { Ecosystem services } \\
\text { provided by AGs }\end{array}$ & $\begin{array}{l}\text { The cities of } \\
\text { Manchester (UK) and } \\
\text { Poznań (Poland) }\end{array}$ & & & $\sqrt{ }$ & & & $\sqrt{ }$ \\
\hline
\end{tabular}


Table 1. Cont.

\begin{tabular}{|c|c|c|c|c|c|c|c|c|}
\hline \multirow[b]{2}{*}{ Papers } & \multirow[b]{2}{*}{$\begin{array}{c}\text { Thematic Scope } \\
\text { of Paper }\end{array}$} & \multirow[b]{2}{*}{$\begin{array}{l}\text { Spatial Scope } \\
\text { of Paper }\end{array}$} & \multicolumn{6}{|c|}{ Research Questions } \\
\hline & & & $\begin{array}{l}\text { How do AGs use } \\
\text { Blue and Green } \\
\text { Infrastructure? }\end{array}$ & $\begin{array}{c}\text { What } \\
\text { Problem(s) do } \\
\text { AGs Solve } \\
\text { Today? }\end{array}$ & $\begin{array}{l}\text { What Kind of } \\
\text { Benefits do AGs } \\
\text { Provide? }\end{array}$ & $\begin{array}{l}\text { Do AGs Possess } \\
\text { Implementation } \\
\text { and Management } \\
\text { Capabilities? }\end{array}$ & $\begin{array}{l}\text { Can AGs be } \\
\text { Treated as } \\
\text { Economically } \\
\text { Efficient? }\end{array}$ & $\begin{array}{l}\text { What are the } \\
\text { Advantages of AGs } \\
\text { versus Other } \\
\text { Possible } \\
\text { Solution(s)? }\end{array}$ \\
\hline \multicolumn{9}{|c|}{ Polish Language Papers } \\
\hline Dymek, Bednorz 2017 [46] & Development of AGs & $\begin{array}{l}\text { The city of Poznań } \\
\text { (Poland) }\end{array}$ & & & & $\sqrt{ }$ & & \\
\hline Kosmala red. 2013 [48] & $\begin{array}{l}\text { The reasons for the } \\
\text { location of AGs in the } \\
\text { city structure }\end{array}$ & $\begin{array}{l}\text { The city of Łódź } \\
\text { (Poland) }\end{array}$ & $\sqrt{ }$ & $\sqrt{ }$ & $\sqrt{ }$ & $\sqrt{ }$ & $\sqrt{ }$ & \\
\hline $\begin{array}{l}\text { Pawlikowska-Piechotka } \\
2010[29]\end{array}$ & $\begin{array}{c}\text { AGs as a form of } \\
\text { recreational } \\
\text { development }\end{array}$ & Polish cities in general & & $\sqrt{ }$ & $\sqrt{ }$ & $\sqrt{ }$ & & \\
\hline $\begin{array}{c}\text { Pawlikowska-Piechotka } \\
2019[49]\end{array}$ & $\begin{array}{l}\text { History and } \\
\text { current use }\end{array}$ & $\begin{array}{l}\text { The city of Warsaw } \\
\text { (Poland) }\end{array}$ & & $\sqrt{ }$ & $\sqrt{ }$ & $\sqrt{ }$ & & $\sqrt{ }$ \\
\hline
\end{tabular}




\section{Results}

\subsection{Key Features of NBSs}

Despite the existence of a number of uncertainties regarding the term nature-based solutions $[4,10,39]$, there are nevertheless numerous aspects on which the researchers agree on (Table 2) $[9,10,37,38,50,51]$. Among the key features of NBSs, the following characteristics should be mentioned:

- NBSs are based on the use of blue and green infrastructure

- NBSs solve urgent problem(s)

- NBSs provide multiple benefits.

- NBSs possess implementation and management capabilities

- NBSs are economically efficient

- $\quad$ NBSs exceed other possible solution(s) (Table 3)

Table 2. Examples of definitions and goals of the NBS concept.

\begin{tabular}{|c|}
\hline Definitions and Goals of NBSs According to Selected Papers \\
\hline $\begin{array}{l}\text { "Actions address environmental, social, and economic challenges simultaneously by maximizing } \\
\text { the benefits provided by nature" [9]. }\end{array}$ \\
\hline $\begin{array}{l}\text { "Conscious use of nature to help urban inhabitants address various environmental, social, and } \\
\text { economic challenges" [50]. }\end{array}$ \\
\hline $\begin{array}{l}\text { "A promising means to address a number of societal challenges arising from climate change and } \\
\text { urbanization, with multiple social, environmental, and economic co-benefits" [10]. }\end{array}$ \\
\hline Action "inspired by, supported by, or copied from nature" [9] (EC 2015). \\
\hline $\begin{array}{l}\text { "Mimicking nature should be the dominant approach for using NBSs to restore the urban scape } \\
\text { and city ecosystem services" [37]. }\end{array}$ \\
\hline $\begin{array}{l}\text { "Multifunctional green interventions delivering upon the social, environmental, and economic } \\
\text { pillars of suitable development" [38]. }\end{array}$ \\
\hline $\begin{array}{l}\text { "Actions that alleviate a well-defined societal challenge employ ecosystem processes of spatial, } \\
\text { blue, and green infrastructure networks, and are embedded within viable governance or business } \\
\text { models for implementation" [51]. }\end{array}$ \\
\hline $\begin{array}{l}\text { "Enhancing sustainable urbanisation; restoring degraded ecosystems; developing climate change } \\
\text { adaptation and mitigation; and improving risk management and resilience" [9]. }\end{array}$ \\
\hline “Nature-based solutions support economic development" [9]. \\
\hline
\end{tabular}

In addition to the key features of NBSs mentioned above, there are some minor examples of limited importance from a classification point of view that have not been widely discussed so far. As most cities have limited areas of open space that can be used for green areas, comprehensive analyses are needed to understand the impact of the size of the solution on a service provision [5]. To be effective, NBSs must be of relevant size to ensure the stability of ecological processes and to have long-term effects [7]. As a result, the size of a solution may vary from the local micro-scale (e.g., a green wall) to the trans-regional scale (e.g., flood protection along the coast), depending on the level of disturbance [54]. Taking the factor of social acceptance into account, special attention should be given to the aesthetic aspects of NBSs [7] and their visual amenity as perceived by stakeholders [18]. We cannot exclude, however, an intervention from the set of NBSs because its visual values are not appreciated by society: this solution may provide other important cultural ecosystem services (CES).

Summing up, Figure 2 presents the most important characteristics of NBSs in comparison to solutions that cannot be treated as nature-based according to the current criteria (see Tables 2 and 3). It can be concluded that NBSs can be defined as "solutions based on the use of plants, water, and/or chemical processes, oriented toward urgent problem(s), simultaneously addressing multiple challenges by providing environmental, social, and 
economic benefits and having considerable implementation and management potential and high economic efficiency".

Table 3. Explanation of key features of NBSs.

Key Features of NBSs

Utilization of Blue/Green Infrastructure

Solving Urgent (Global) Problems

Provision of Multiple Services

Implementation and Management Capabilities

Economic Efficiency

NBSs' Excess Other Possible Solution(s)

\section{Explanation}

The use of nature, by adopting and copying it, constitutes the basis of NBS concept [9].

The utilization of plants, water, and/or natural chemical processes such as phytoremediation and phytostabilization is a priority rather than a supplement to engineering infrastructure [50]. An NBS may be based on both a pure green solution or a solution that merges natural processes and grey infrastructure [39].

NBSs have the potential to address urgent and generally global challenges by dealing with aspects such as sustainable urbanization, restoration of degraded ecosystems, climate change adaptation and mitigation, improvement of risk management and resilience, food security, disaster risk reduction, and economic development $[9,10]$.

NBSs should be treated as a dynamic scheme of ecosystem service provisioning, offering multiple benefits simultaneously [9]. They include three pillars of sustainability: environmental (e.g., the promotion of biodiversity, decrease of flooding risk, enhancement of water resilience, and to the climate changes adaptations and carbon sequestration); social (improvement of mental and physical health, social cohesion, and portion of outdoor activity); and economic (production of low-cost food, creation of green jobs, use of the renewable sources of energy, and reduction of watering and energy costs) $[3,10,13]$.

Any intervention considered as nature-based requires flexible and transparent models of governance to measure, verify, replicate, maintain, and if necessary alter and improve the solutions adopted $[7,27,37]$. It includes both the use of existing policy framework and the changes in policy, legislation, and spatial planning [52]

NBSs have a potential to be of high economic efficiency by promoting "transitions" from a resource-intensive growth model towards a more resource-efficient model. This efficiency, in relation to the NBSs, means that the cost of a solution's implementation, maintenance, or transformation should not exceed the potential environmental and social benefits $[5,9,26,27]$.

A given implemented NBS should exceed other possible solutions in terms of their effectiveness in relation to the environmental, social, and economic aspects resulting from the local conditions [9]. There is a lack of site-specific studies, however, on the effectiveness of these interventions compared to alternatives ones [53].

Features that exclude a solution from being considered as an NBS:

- Focusing on solving only the environmental problem

- A solution badly affecting the ecological values of a given area

- Environmental engineering projects using only artificial building materials

- Solutions with high economic, social, or environmental costs

- Short-term solutions requiring continuous renewal

- Solutions without social acceptance

Examples include: protection actions aimed at the maintenance of endangered plant species in urban environments; developing a recreational park in a place of rare multi-species meadows; development of a concrete dam against flooding; an exotic botanical park that needs continuous heating and watering; planting of non-drought-resistant plants that die each year and therefore need to be planted again.

\subsection{Research Questions}

The detection of six key features of the NBS concept led to the formulation of six questions which allow for the assessment of any historical green/blue solution to be considered as an NBS. In this paper they were used to assess the potential of Polish AGs. They are as follows:

1. How do AGs use blue and green infrastructure?

2. What problem(s) do AGs solve today?

3. What kind of benefits do AGs provide?

4. Do AGs possess implementation and management capabilities?

5. Can AGs be treated as economically efficient?

6. What are the advantages of AGs versus other possible solution(s)? 


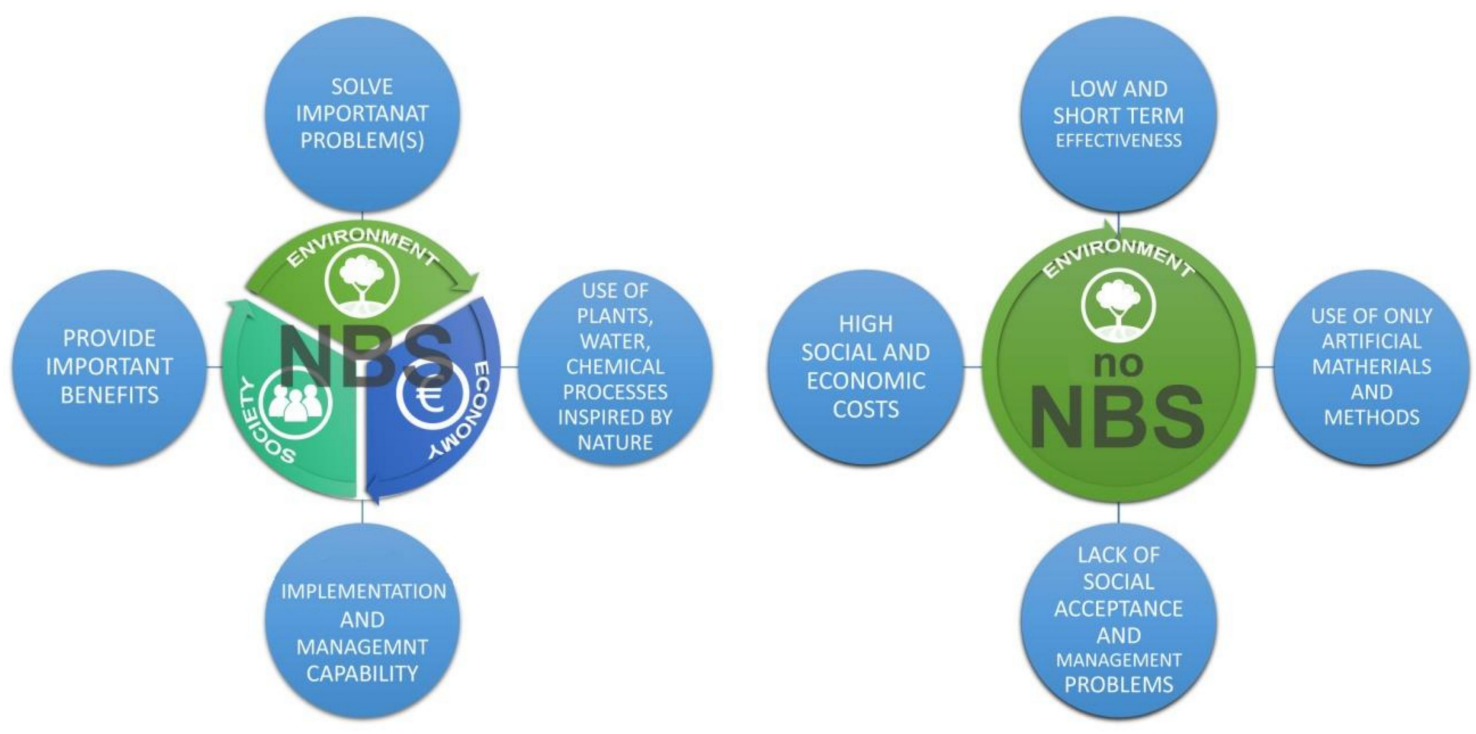

Figure 2. Summary of the key features and non-features of NBSs, based on the example of a solution directed solely at an environmental problem.

4.3. Possibilities and Obstacles for Considering Polish AGs as an NBS Based on the Use of Historical Infrastructure

4.3.1. How Do AGs Use Blue and Green Infrastructure?

The key "building material" of AGs is greenery: edible and flourishing plants, fruit trees, herbs and grasses, and in some cases also water structures. Artificial structures such as cabins are present in $98 \%$ of the gardens, paved ground in $22.5 \%$, sheds in $13 \%$, and other structures such as garages and greenhouses in $8 \%$ [33]. Their area, however, is quite small when compared to green/blue infrastructures since the average area of cabins equals $15.5 \mathrm{~m}^{2}$ [28], which is about $5 \%$ of the total area (a standard plot has $300 \mathrm{~m}^{2}$ ). Therefore, from this perspective, AGs can be classified as an ecosystem-based solution.

Another aspect refers to the extent to which they are inspired by or copied from nature. The level of inspiration depends on the individual owner's preferences. Some Polish owners promote plant compositions similar to the natural ones, inspired by forests or meadow habitats, whereas others select popular and/or easy to maintain plants, such as thujas and lawns, or decide to intensify the use of edible species [28]. As there is no consensus among researchers regarding the imitation of nature by NBSs [10,37], all approaches have the potential to be considered as an NBS. Besides, numerous studies conducted in relation to different Polish cities showed that AGs exhibited high plant species richness and diversity. The study conducted in 2009 among 46 urban allotment gardeners in three Polish cities documented 257 botanical taxa [32] and 358 species of flora recorded in 11 representative allotment garden estates (total area $150 \mathrm{ha}$ ) in the city of Poznań [41]. The same studies also recorded low synanthropization levels and very few invasive species. They also confirmed that generally urban gardeners were attached to traditional foods and ornamental plants [32,41].

\subsubsection{What Problem(s) Do AGs Solve Today?}

At the moment of their creation, most AGs in Poland aimed at solving urgent economic problems, such as the provision of food to the poorest, although the first garden (called "Sunbaths") created at the end of the 19th century served a recreational function [29]. Thus, this solution met both economic and social challenges. However, from the point of view of the requirements set for NBSs, the question to be asked is what kinds of problems are they solving today? 
According to the EC report [9] about NBSs, AGs should address urgent and generally global challenges by dealing with aspects such as sustainable development, restoration of degraded ecosystems, climate change adaptation and mitigation, improvement of risk management and resilience, food security, disaster risk reduction, and economic development. Based on this list, Polish AGs have the greatest contribution to the vision of sustainable development goals [42] including tackling poverty, promoting good health and wellbeing, sustainable cities, responsible consumption, and life on land [55,56] (Figure 3A).

\section{A. POTENTIAL OF POLISH ALLOTMENT GARDENS TO BE CONSIDERED AS NBS}

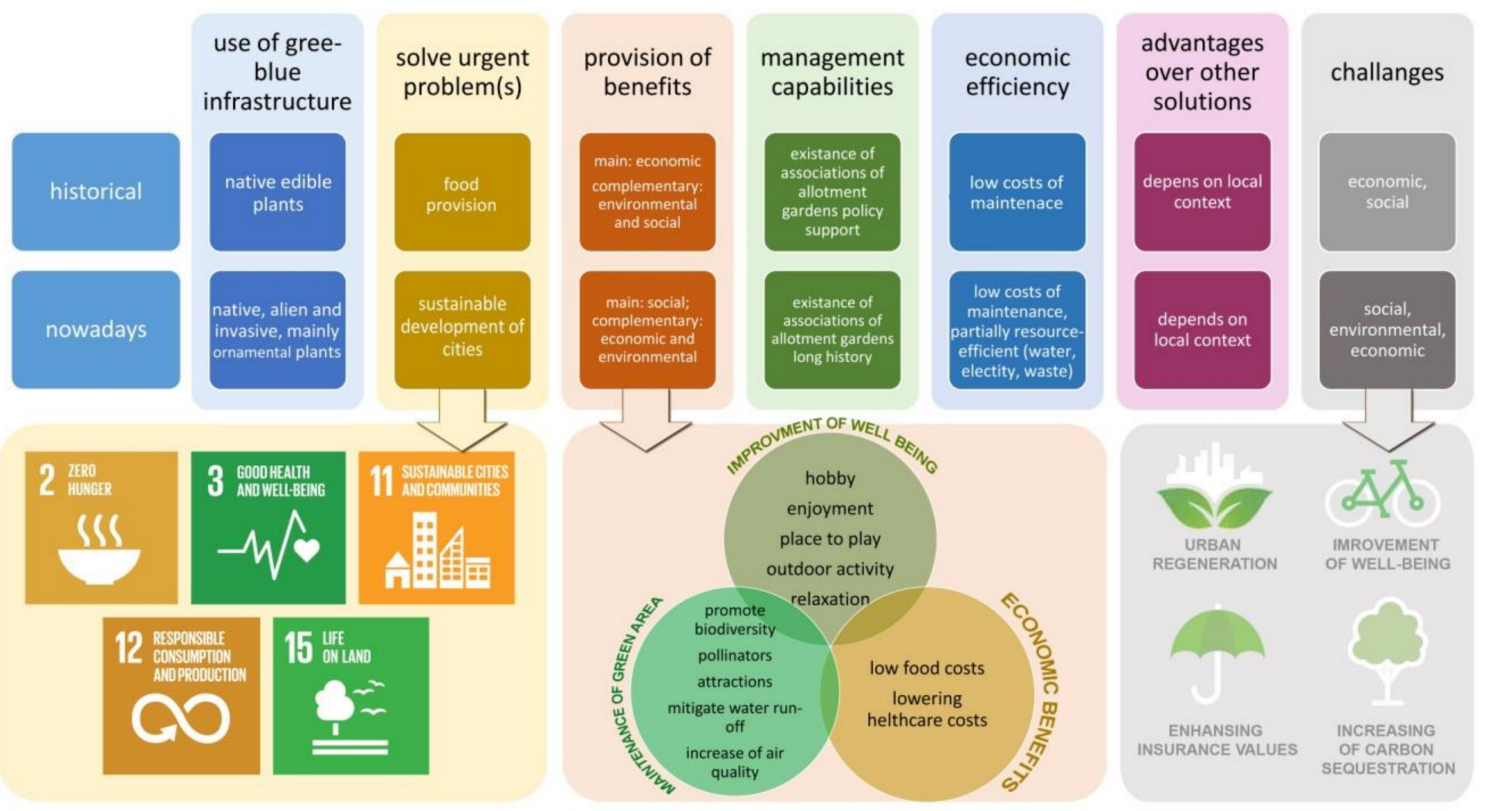

B. OBSTACLE OF POLISH ALLOTMENT GARDENS TO BE CONSIDERED AS NBS

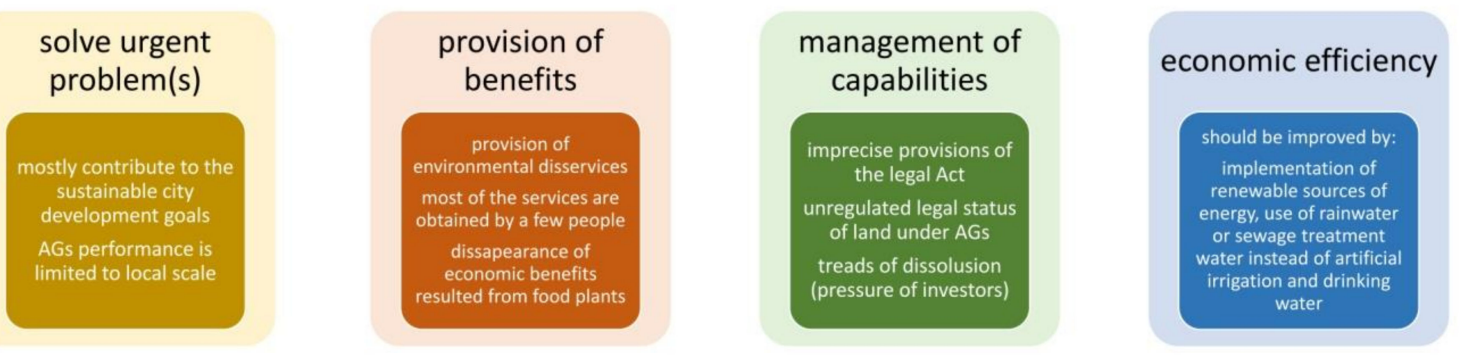

Figure 3. The analysis of AGs: (A) as an example of green infrastructure with the potential to be considered as a NBS; (B) obstacle of AGs to be considered as a NBS.

They address the need for recreational, productive structures of a certain environmental quality and compensate for the need for green areas within the city structure both in terms of social and environmental needs [32,48]. In Poland, they help tackle many of the urgent environmental problems caused by urbanization, including those related to the urban heat island effect, increased humidity, the creation of local microclimates, improvements in air quality, and the reduction of noise [29].

Regarding AGs' contribution in solving urgent problems, the size and scale factor seems to be crucial. The combinations and configurations of vegetation in different sizes can maximize carbon capture, shading provision, and improve the quality of citizens' lives [9]. Thus, to be effective, NBSs must be of relevant size to ensure the stability of ecological processes and to have long-term effects $[1,7,18]$. Polish AGs usually cover about $2-3 \%$ of the city's area [29] which is a scale appropriate to tackle urgent problems locally, 
rather than on national or global level. As the effectiveness of each solution is limited in a space context, the evaluation and monitoring of AGs performance as a solution serving to tackle problems should be based on a nested approach based on cross-scales analysis [1].

\subsubsection{What Kind of Benefits Do AGs Provide?}

AGs are multifunctional elements of urban space with the potential to constitute a source of a set of ecosystem services. Direct benefits, such as food provision, have been noticed from the moment of their establishment but simultaneously many indirect benefits have existed and still continue to exist. The impact on the improvement of the quality of life, however, is most commonly emphasized. AGs provide an enjoyable and profitable hobby, relaxation, contact with nature, a sense of tranquillity, an outdoor activity, and health improvements $[29,44,48]$. Such green structures in countries like Poland are used by people with different social statuses and passions: including children, the unemployed, the elderly and the disabled, nature lovers, and amateur gardeners [29,31,57]. Elderly people, however, constitute the majority of their users: at the local scale (the city of Łódź) the average age of the gardens' users was estimated at 62.5 years [33].

The provision of multiple social benefits, however, is quite limited in Poland (Figure 3B) [40]. First of all, it refers to the improper use of AGs in terms of illegal living, being used as shelters for the homeless, unauthorized construction, illegal garbage burning (which produces smog), as well as their transformation into residential houses during the summer season [35]. Moreover, abandoned plots compromise aesthetic values - they are perceived negatively by citizens and come to be regarded as dangerous places. Besides, the issue of environmental justice should be highlighted. In Poland, AGs are family spaces with restricted access, surrounded by fences or hedges. As a result, they provide direct and personal services only to a limited percentage of citizens. Such inequality was seen recently when access to public green spaces was banned for a few weeks due to the COVID-19 pandemic. This intensified many urban inhabitants' feelings of exclusion, as they could only watch owners relaxing in their gardens without having any legal possibility to use these green areas for themselves [from the Polish Gardening Association website http://pzd.pl/].

Regarding the environmental pillar, AGs generally offer benefits such as local climate mitigation, water regulation, promotion of biodiversity, provision of habitats, and soil microbial activity [29]. In Poland, however, many gardens deserve attention for nature-related reasons. This mainly derives from the following issues: numerous species of herbaceous and woody plants have been introduced [44], a large number of cats fed by garden owners reduces bird activity, while excessive use of fertilizers causes soil pollution [40], and a vast area of soils in the city zone are excessively contaminated which makes them unsuitable for vegetable and fruit production and thus they require regeneration. It results from the fact that there are no regulations referring to environmental issues such as planted species, water use, or the use of herbicides. Consequently, the owners are free to manage their family gardens as they wish, which in many cases results in negative environmental outputs, such as the introduction of invasive species and soil pollution.

The direct economic benefits resulting from food provision have gradually diminished, not only in Poland, due to edible plants being replaced by those considered more visually attractive. In 1980, the area designated for crops covered an average of $34 \%$ of each plot. Nowadays, this area has declined to an average of $16 \%$ [58,59]. This shift was also proven by the research conducted [32] in relation to botanical and landscape diversity. It indicated that the majority of taxa were used as ornaments (191 taxa), followed by food (52), and medicinal plants (5). As a result, these green structures are losing their main economic potential, despite this being the reason for their creation [29].

\subsubsection{Can AGs Be Treated as Economically Efficient?}

Polish AGs have low maintenance costs: electricity, water, waste collection, and management are divided among all the owners of the AGs and do not include the cost of rent (provided that the Polish Garden Association does not pay usage fees to the 
land owners). A yearly fee covering the expenses for ongoing maintenance, repairs, and renovations of the garden infrastructure is paid by owners to the Polish Garden Association [48].

Most of the Polish AGs fit the NBS requirements in terms of economic efficiency too. First, there is a legal obligation to save water and many owners collect and use rainwater for watering. Second, most gardens do not have a developed lighting network, this being limited to spotlights, while in the autumn and winter, electricity is disabled. Third, every AG should be equipped with a composter and, since 2013, AGs have been obligated to pay a fee to a municipal company for waste collection, compelling owners to reduce the amount of garbage they produce [40]. In addition, renewable sources of energy such as photovoltaic panels are becoming more and more popular, especially among younger people [from the Polish Gardening Association website http://pzd.pl/]. Their current use, however, is still limited and only a small proportion of cabins are equipped with such panels.

Of course, the efficiency of these historical green structures can be improved. For NBSs to be considered to be highly efficient they should be cost- and resource-efficient, including the use of rainwater or treated sewage water instead of artificial irrigation and drinking water. Furthermore, smart irrigation control techniques should be implemented to avoid overwatering or waterlogging, which can cause plants to die. Of course, any urban green infrastructure always generates some maintenance costs deriving from the changeable nature of greenery (re-planting because of the diseases and physical damage, cleaning the leaves, and mowing and trimming) as well as the need to maintain high aesthetic values [5].

4.3.5. What Are the Environmental/Social/Economic Advantages and Disadvantages of AGs Versus Other Possible Solution(s)?

To address this question, three possible NBSs are compared with AGs. As these gardens are a historical element of many Polish cities, the situation of gardens' transformation is considered by: (1) merging and transforming them into a public garden; (2) partial liquidation (leaving some trees behind) and the planting of an urban forest; and (3) total liquidation, involving the creation of a building covered by green roofs and walls.

Urban forests stand out as a green solution due to their environmental values: they provide a variety of ecosystem services, including air purification, global climate regulation, urban temperature regulation, noise reduction, and runoff mitigation [40]. They also offer considerable recreational opportunities connected with psychological and social health, economic development of the community, and tourism [60]. The achievement of such benefits, however, requires a time lag of a few to several dozen years and their distribution may be affected by various management and social problems [61]. AGs may also serve lots of environmental benefits, as described in previous sections in detail, but depending on the owner's activities and nature preferences they may also compromise local biodiversity due to the introduction of alien and invasive species and the use of herbicides [44].

Public gardens and urban forests remove the main social disadvantages of AGs as they are accessible to all. On the other hand, the number of different types of benefits that they can provide is considerably lower: in the Polish context, the use of common and open space for urban agriculture struggles due to the high risk of vandalism and theft. Moreover, public gardens and forests located within the city structure are unlikely to provide tranquillity and silence owing to problems related to crowds, fast-moving people, littering, theft, and noisy behaviour [61]. In terms of ecology, the comparison between parks and AGs showed that the latter features higher species' richness with a greater proportion of neophytes, which may potentially spread into cities [47].

Green roofs and walls can provide direct economic benefits through the sale of greenfield lands located in attractive areas as well as the sale or rent of residential, office, and service areas. Furthermore, green roofs and walls substantially reduce energy and water consumption. The economic benefits of AGs are much smaller but are both direct (e.g., food provision) and indirect (e.g., reduced treatment costs). 
The advantages and disadvantages of AGs in relation to NBSs is dependent on the local context (Figure 4). It should be emphasized here that NBSs are likely to be better understood in the long-run, referring to all spheres of potential outputs: environmental (biodiversity, climate mitigation, carbon sequestration), social (physical and mental health), and economic (management costs). Besides, in the long-run, trade-offs (the increase of one service causing the decrease of another service) and synergies (the increase of one service causing the increase of another service) may be better recognized, and random relations (occurring accidentally, once in a while) may be distinguished from the permanent ones (long-term relations proven in relation to different kinds of services) [4]. Only some effects may be seen immediately after implementation. This is very important, considering that Polish AGs are rooted in local traditions and contribute to a sense of place. Despite the problems and uncertainties that they have provoked, many argue that their presence in the urban fabric should become permanent $[29,44]$.
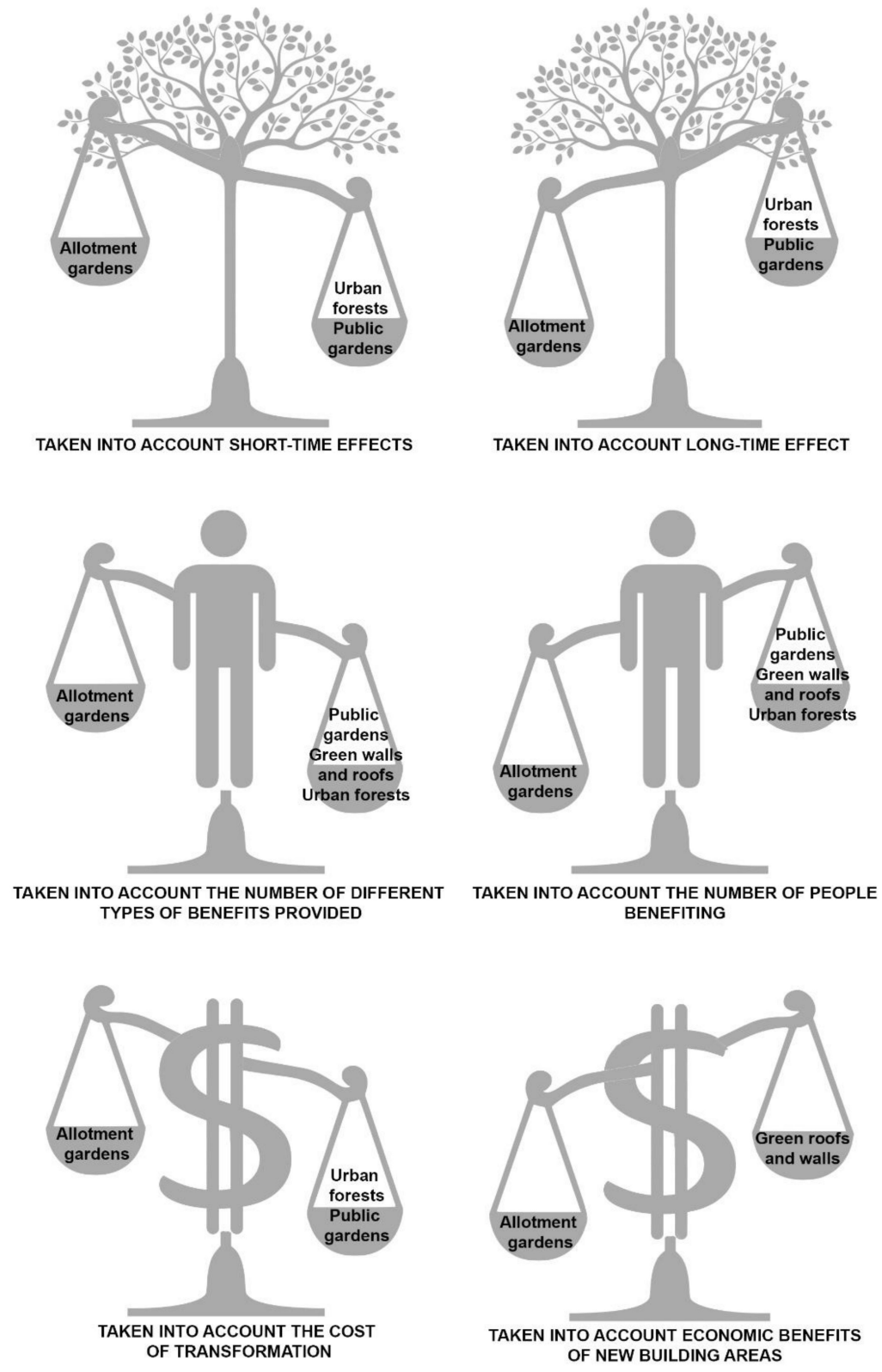

Figure 4. Advantages and disadvantages of AGs versus other possible solutions: public gardens, urban forests, and green roofs and walls. 


\section{Discussion}

Green/blue city infrastructure is increasingly becoming considered not only as support for biodiversity conservation but also as a source of additional environmental, social, and economic benefits $[62,63]$. Consequently, it has the potential to contribute to climate change mitigation, adaptation in urban areas, and enhanced sustainability of catchment systems [4]. Besides, this infrastructure promotes urban biodiversity governance through urban planning processes, which include the range of actions and capacities for governing biodiversity at the local (city) level, referring not only to the importance of science-based targets, but also to the values that different communities hold for nature [6]. Urban green/blue infrastructure provides a range of social benefits, including recreation, relaxation, a place to meet with friends, and it contributes to physical and mental health [17]. From this perspective, multiple values of the ecosystem services of urban gardens qualify them as potential NBS to urban challenges [64]. The result of our research proved this statement, as multiple studies on Polish AGs showed that they positively contribute to solving environmental problems by decreasing urban heat island effect, increasing humidity, improving air quality, reducing noise, and increasing plant species' richness and diversity $[29,32,41]$. In relation to the social pillar, AGs provide an enjoyable and profitable hobby, relaxation, contact with nature, sense of tranquillity, outdoor activity, and health improvements $[29,31,57]$. Benefits in the economic sphere result from the fact that the analysed gardens are a source of fresh food (unfortunately this function is continuously disappearing), serve as a place for holidays free of charge, and they can be partially treated as cost- and resource-efficient in terms of their use of water and electricity. Besides, the analysis on the research question referring to the advantages and disadvantages of AGs versus other possible solutions, showed that they exceed other possible solutions, for example in the number of types of benefits provided. Thus, Polish AGs address some of the sustainable development goals including lessening poverty, increasing good health and wellbeing, sustainable cities, responsible consumption, and life on land. Nevertheless, the in-depth analysis presented in this paper using the example of AGs has shown that the possession of all the major qualities linked to NBSs does not axiomatically render something a successful ecosystembased solution. The authors agree with Nesshöver et al.'s [1] conclusion that green/blue infrastructure is a fairly similar concept to NBSs in some areas and that under certain circumstances the two terms can be regarded as synonymous. The biggest difference pertains to the contrasting meanings of the terms infrastructure and solution, the former referring to the structures needed for a society or enterprise to operate and the latter to solving the problem(s) encountered. Similarly, based on a review of more than 100 papers, Hanson et al. [64] concluded that there is a close link between the NBS concept and green infrastructure, but the former adds the "idea of nature bringing a solution". NBS is not just another buzz-term but an innovative concept that can constitute a tool of sustainable city development directed towards solving urgent, mostly global, environmental problems. Moreover, NBSs stand out from other, "traditional" ecosystem-based solutions for being more efficient and cost-effective [65]. To obtain this high level of efficiency, AGs should be equipped with irrigation systems that use rainwater or treated sewage water and be based on renewable sources of energy. Smart irrigation control techniques should be included as an example of advanced solutions. Governance capability is another hallmark of NBSs. Certainly, taking the multi-institutional character of NBSs into account, innovative governance to promote their uptake and success is necessary [38].

The example of Polish AGs showed that these historical urban green structures have clear potential to be considered as an NBS, which is fairly consistent with Van der Jagt et al.'s [38] point of view in relation to communal gardens as a means of strengthening social resilience. Langemeyer et al. [66] have even emphasized that in some areas they stand out for their technological innovations, as they have the capacity to represent socially innovative naturebased approaches. In Poland, however, NBSs generally seem to have attracted relatively little attention, manifesting a fairly low rate of acceptance and limited visibility [50]. Many chances to preserve green spaces, including AGs, have been missed, along with the opportunities to 
introduce new forms of green/blue infrastructure that would fit the scope of NBSs. Furthermore, historical green structures that have existed for a long time are not necessarily seen as an innovation and therefore are not promoted. This study has shown that in the Polish context there are four major obstacles for considering AGs as NBSs. The first refers to the partial realising of NBS set goals as AGs contribute only to the sustainable cities development goals and their performance is limited to local (city district(s) or city) scale. The second obstacle is connected with the irregular distribution of benefits, both among NBS pillars and types of citizens. In the Polish context, AGs provide environmental disservices such as the introduction of herbaceous and woody plants, harm caused by cats fed by garden owners, and the soil pollution. Social problems are connected to the fact that AGs are private lands and thus are used by a narrow group of people (owners and their guests). The third obstacle results from the existence of institutional barriers: imprecise provisions of the legal Act, unregulated legal status of land, and threats of dissolution as a result of investors' pressure. Fourth, Polish AGs showed some deficiencies in economic efficiency resulting from the low use of renewable sources of energy and the use of artificial irrigation and drinking water instead of rainwater or treated sewage water. Most of these obstacles have resulted from the institutionally outdated structure of the Polish Garden Association and the high level of freedom that owners enjoy in maintaining their gardens. As a result, the benefits provided by NBSs are being obtained only partially. Several actions must be taken to remove the obstacles in the way of AGs becoming an effective NBS in Poland, although these will be difficult to realize given the traditional rooting of the Association as a management body of AGs and the general low involvement of Polish society in policy practice. These actions are presented in Table 4. The institutional support and characteristics of garden users, together with the proper management of environmental components, however, were intended to be the key factors in strengthening the role of AGs as NBSs $[50,66,67]$. Thus, strengthening management capability and increasing owners' awareness of their legal responsibilities should be regarded as indispensable repair management actions.

Table 4. Actions to be taken in relation to this Polish case study to remove the obstacles that exist for considering AGs as effective NBSs.

What Can Be Done

Removal of the institutional barriers, including the introduction of legal acts precisely regulating all principles, and the adoption of land-use plans in order to ensure gardens' future existence.

Regulation of financial aspects (the introduction of the recompense law in the case of the dissolution of AGs and their obligations; the replacement of AGs with another element of urban greenery; regulation of fees) [44].

\section{Obstacles that Are Difficult to Remove}

Removal of environmental inequalities (AGs by definition are owned by families and no trespassing is allowed).

Limitation of social arbitrariness (a top-down ban on the introduction of invasive species and the use of herbicides and pesticides cannot be imposed).

Ensuring stakeholders' participation through elaborating the

policy model involving government and non-government actors, including owners and other citizens.

Intensification of multiple benefits (edible plants, more trees

and fewer lawns, native and protected species, ponds, and educational function for the general public).

Intensification of the implementation of renewable sources of energy (solar panels)

The use of rainwater or treated sewage water instead of artificial irrigation and drinking water

Transformation of abandoned AGs and their communal areas to urban parks (or even pocket gardens).

Educational activities directed towards owners related to the environmental consequences of gardening practices. 


\section{Conclusions}

The example of Polish AGs fulfils most of the requirements of NBSs, such as the use of plants and water, solving urgent problems at the local scale, the inclusion of the environmental, social, and economic pillars of sustainable development, a certain level of economic efficiency, and certain advantages of AGs versus other possible solutions. These historical urban green/blue infrastructures, however, feature some important obstacles including: partial vision of set NBS goals, irregular distribution of benefits, the existence of institutional barriers, and some deficiencies in economic efficiency. Thus, the link between the NBS and AG concepts can be expressed as follows: NBSs aim to utilize all the benefits provided by green/blue infrastructure to address urgent problems in the most effective way possible. Nevertheless, as there is a time lag between launching a new concept and its implementation in practice, AGs together with other historical urban green/blue infrastructure may be regarded as a kind of unsophisticated NBS in which effectiveness is limited. Such structures may positively contribute to sustainable urban development, climate change mitigation and adaptation, flood protection, and improved resilience until more innovative and efficient solutions have been tested and their long-term operability verified. These new solutions may be created as independent structures or (historical) green/blue infrastructure may be enlarged, fitted out, linked, and improved to implement NBS projects.

Author Contributions: Conceptualization, B.S.-Ś.; methodology, B.S.-Ś.; software, B.S.-Ś., M.M.-Ś.; validation, B.S.-Ś.; formal analysis, B.S.-Ś.; investigation, B.S.-Ś.; resources, B.S.-Ś.; data curation, B.S.S.; writing—original draft preparation, B.S.-Ś.; writing—review and editing, M.M.-Ś.; visualization, B.S.-Ś., M.M.-Ś., A.B.-M.; supervision, B.S.-Ś.; project administration, B.S.-Ś., M.M.-Ś.; funding acquisition, M.M.-Ś., A.B.-M. All authors have read and agreed to the published version of the manuscript.

Funding: The research was funded by the Ministry of Science and Higher Education (Poland) for the dissemination of science (766/P-DUN/2019).

Informed Consent Statement: Not applicable.

Data Availability Statement: Not Applicable.

Conflicts of Interest: The authors declare no conflict of interest.

\section{References}

1. Nesshöver, C.; Assmuth, T.; Irvine, K.N.; Rusch, G.M.; Waylen, K.A.; Delbaere, B.; Haase, D.; Jones-Walters, L.; Keune, H.; Kovacs, E.; et al. The science, policy and practice of nature-based solutions: An interdisciplinary perspective. Sci. Total Environ. 2017, 579, 1215-1227. [CrossRef] [PubMed]

2. US Army Corps of Engineers. CWTS 2013-3-Coastal Risk Reduction and Resilience. Civil Works Directorate; US Army Corps of Engineers: Washington, DC, USA, 2013.

3. Ferreira, V.; Barreira, A.P.; Loures, L.; Antunes, D.; Panagopoulos, T. Stakeholders' engagement on nature-based solutions: A systematic literature review. Sustainability 2020, 12, 640. [CrossRef]

4. Kabisch, N.; van den Bosch, M.; Lafortezza, R. The health benefits of nature-based solutions to urbanization challenges for children and the elderly—A systematic review. Environ. Res. 2017, 159, 362-373. [CrossRef] [PubMed]

5. Xing, Y.; Jones, P.; Donnison, I. Characterization of nature-based solutions for the built environment. Sustainability 2017, 9, 149. [CrossRef]

6. Xie, L.; Bulkeley, H. Nature-based solutions for urban biodiversity governance. Environ. Sci. Policy 2020, 110, 77-87. [CrossRef]

7. Frantzeskaki, N. Seven lessons for panning nature-based solutions in cities. Environ. Sci. Policy 2019, 93, 101-111. [CrossRef]

8. Keesstra, S.; Nunes, J.; Novara, A.; Finger, D.; Avelar, D.; Kalantari, Z.; Cerdà, A. The superior effect of nature-based solutions in land management for enhancing ecosystem services. Sci. Total Environ. 2018, 610-611, 997-1009. [CrossRef]

9. European Commission. Towards an EU Research and Innovation Policy Agenda for Nature-Based Solutions and Re-Naturing Cities; European Commission: Brussels, Belgium, 2015.

10. Ershad Sarabi, S.; Han, Q.; LRomme, A.G.; de Vries, B.; Wendling, L. Key enablers of and barriers to the uptake and implementation of nature-based solutions in urban settings: A review. Resources 2019, 8, 121. [CrossRef]

11. Neumayer, E. Week Versus Strong Sustainability: Exploring the Limits of Two Opposing Paradigms; Edward Elgar Publishing: Cheltenham, UK, 2003.

12. Parker, J.; de Baro, M.E.Z. Green infrastructure in the urban environment: A systematic quantitative review. Sustainability 2019, 11, 3182. [CrossRef] 
13. Parker, J.; Simpson, G.D. Public green infrastructure contributes to city livability: A systematic quantitative review. Land 2018, 7, 161. [CrossRef]

14. Venkataramanan, V.; Packman, A.I.; Peters, D.R.; Lopez, D.; McCuskey, D.J.; McDonald, R.I.; Young, S.L. A systematic review of the human health and social well-being outcomes of green infrastructure for stormwater and flood management. J. Environ. Manag. 2019, 246, 868-880. [CrossRef] [PubMed]

15. Sowińska-Świerkosz, B. Critical review of landscape-based surrogate measures of plant diversity. Landsc. Res. 2020, 45,819-840. [CrossRef]

16. Zuniga-Teran, A.; Gerlak, A. A multidisciplinary approach to analyzing questions of justice issues in urban greenspace. Sustainability 2019, 11, 55. [CrossRef]

17. Raymond, C.M.; Frantzeskaki, N.; Kabisch, N.; Berry, P.; Breil, M.; Nita, M.R.; Calfapietra, C. A framework for assessing and implementing the co-benefits of nature-based solutions in urban areas. Environ. Sci. Policy 2017, 77, 15-24. [CrossRef]

18. Raymond, C.M.; Breil, M.; Nita, M.R.; Kabisch, N.; de Bel, M.; Enzi, V.; Berry, P. An Impact Evaluation Framework to Support Planning and Evaluation of Nature-based Solutions Projects. Report Prepared by the EKLIPSE Expert Working Group on Nature-based Solutions to Promote Climate Resilience in Urban Areas; Centre for Ecology and Hydrology: Wallingford, UK, 2017.

19. Sang, A.O.; Knez, I.; Gunnarsson, B.; Hedblom, M. The effects of naturalness, gender, and age on how urban green space is perceived and used. Urban For. Urban Green. 2016, 18, 268-276. [CrossRef]

20. Vujcic, M.; Tomicevic-Dubljevic, J.; Grbic, M.; Lecic-Tosevski, D.; Vukovic, O.; Toskovic, O. Nature based solution for improving mental health and well-being in urban areas. Environ Res. 2017, 158, 385-392. [CrossRef]

21. Young, Y.E.; Passarelli, S.; Lovell, R.; Ringler, C. Gendered perspectives of ecosystem services: A systematic review. Ecosyst. Serv. 2018, 31. [CrossRef]

22. Calvet-Mir, L.; March, H.; Corbacho-Monné, D.; Gómez-Baggethun, E.; Reyes-García, V. Home garden ecosystem services valuation through a gender lens: A case study in the Catalan Pyrenees. Sustainability 2016, 8, 718. [CrossRef]

23. Martín-López, B.; Iniesta-Arandia, I.; García-Llorente, M.; Palomo, I.; Casado-Arzuaga, I.; Amo, D.; Gómez-Baggethun, E.; Oteros-Rozas, E.; Palacios-Agundez, I.; Willaarts, B.; et al. Uncovering ecosystem service bundles through social preferences. PLoS ONE 2012, 7, e38970. [CrossRef]

24. Jefferson, R.L.; Bailey, I.; Richards, J.P.; Attrill, M.J. Public perceptions of the UK marine environment. Mar. Policy 2014, 43, 327-337. [CrossRef]

25. Bush, J.; Doyon, A. Building urban resilience with nature-based solutions: How can urban planning contribute? Cities 2019, 95, 102483. [CrossRef]

26. Faivre, N.; Fritz, M.; Freitas, T.; de Boissezon, B.; Vandewoestijne, S. Nature-based solutions in the EU: Innovating with nature to address social, economic and environmental challenges. Environ. Res. 2017, 159, 509-518. [CrossRef] [PubMed]

27. Maes, J.; Jacobs, S. Nature-based solutions for Europe's sustainable development. Conserv. Lett. 2017, 10, 121-124. [CrossRef]

28. Duś, E. Recreational use and health functions of allotments gardens in the Katowice conurbation, Poland. Environ. Socio Econ. Stud. 2014, 2, 16-25. [CrossRef]

29. Pawlikowska-Piechotka, A. Tradition of Allotment Gardens in Poland; Novae Res: Gdynia, Poland, 2010; 104p, ISBN 978-8361194118. (In Polish)

30. Barthel, S.; Parker, J.; Ernstson, H. Food and green space in cities: A resilience lens on gardens and urban environmental movements. Urban Stud. 2013, 52, 1321-1338. [CrossRef]

31. Henkel, M. 21st Century Homestead. Sustainable Agriculture; Lulu Press: Morrisville, CN, USA, 2015; pp. 1-306.

32. Klepacki, P.; Kujawska, M. Urban allotment gardens in Poland: Implications for botanical and landscape diversity. J. Ethnobiol. 2018, 38, 123-137. [CrossRef]

33. Szkup, R. Use of Family Allotment Gardens by a Metropolitan Community; Wydawnictwo Uniwersytetu Łódzkiego: Łódź, Poland, 2013; p. 246, (In Polish). Available online: https://wydawnictwo.uni.lodz.pl/produkt/uzytkowanie-rodzinnych-ogrodowdzialkowych-rod-przez-spolecznosc-wielkomiejska/ (accessed on 12 January 2021).

34. Poniży, L.; Stachura, K. Future of allotment gardens in the context of CITY spatial policy-A case study of Poznan. Queastiones Geogr. 2017, 36, 121-127. [CrossRef]

35. Moskalonek, Z.; Połom, M.; Puzdrakiewicz, K. Changes in the function of allotment gardens in an attractive location based on the example of tri-city in Poland. Land 2020, 9, 464. [CrossRef]

36. Duś, E. Allotment gardens and spatial development-Two case studies from the Katowice conurbation, Poland. Environ. Soc.-Econ. Stud. 2013, 1, 41-51. [CrossRef]

37. Krauze, K.; Wagner, I. From classical water-ecosystem theories to nature-based solutions—Contextualizing nature-based solutions for sustainable city. Sci. Total Environ. 2019, 655, 697-706. [CrossRef]

38. Van der Jagt, A.P.N.; Szaraz, L.R.; Delshammar, T.; Cvejić, R.; Santos, A.; Goodness, J.; Buijs, A. Cultivating nature-based solutions: The governance of communal urban gardens in the European Union. Environ. Resour. 2017, 159, 264-275. [CrossRef] [PubMed]

39. Eggermont, H.; Balian, E.; Azevedo, J.M.N.; Beumer, V.; Brodin, T.; Claudet, J.; Fady, B.; Grube, M.; Keune, H.; Lamarque, P. Nature-based solutions: New influence for environmental management and research in Europe. GAIA 2015, 24, 243-248. [CrossRef]

40. Bartłomiejski, R.; Kowalewski, M. Polish urban allotment gardens as 'slow city' enclaves. Sustainability 2019, 11, 3228. [CrossRef]

41. Borysiak, J.; Mizgajski, A.; Speak, A. Floral biodiversity of allotment gardens and its contribution to urban green infrastructure. Ekon. Sr. 2016, 4, 292-306. [CrossRef] 
42. Jasionkowski, R.; Lewandowska-Czarnecka, A. The potential of urban agriculture for sustainability of cities in Poland. Ecol. Quest. 2016, 24, 59-64. [CrossRef]

43. Kabala, C.; Chodak, T.; Szerszen, L.; Karczewska, A.; Szopka, K.; Fratczak, K. Factors influencing the concentration of havy metals in soils of allotment garden in the city of Wroclaw, Poland. Fresenius Environ. Bull. 2009, 18, 1118-1124.

44. Trembecka, A.; Kwartnik-Pruc, A. An analysis of the changes in the structure of allotment gardens in Poland. Sustainability 2018, 10, 3829. [CrossRef]

45. Pawlikowska-Piechotka, A. Urban greens and sustainable land policy management (case study in Warsaw). European Cty. 2012, 4, 251-268. [CrossRef]

46. Dymek, D.; Bednorz, L. Zagospodarowanie Rodzinnych Ogórdków Dzaiłkowych (ROD) na przykładzie ROD im. Józefa Chociszewskiego w Poznaniu. Studia Miej. 2017, 25, 133-147. (In Polish) [CrossRef]

47. Speak, A.F.; Mizgajski, A.; Borysiak, J. Allotment gardens and parks: Provision of ecosystem services with an emphasis on biodiversity. Urban For. Urban Green. 2015, 14, 772-781. [CrossRef]

48. Kosmala, M. Ogrody Działkowe w Miastach—Bariera czy Wartość? (Allotment Gardens in Cities—Barrier or Value?); Polskie Zrzeszenie Inżynierów i Techników Sanitarnych: Toruń, Poland, 2013; ISBN 978-83-935740-0-1. (In Polish)

49. Pawlikowska-Piechotka, A. Rodzinne ogrody działkowe w Warszawie tradycja i współczesność. Maz. Studia Reg. 2019, 29, 67-73. (In Polish)

50. Kronenberg, J.; Bergier, T.; Maliszewska, K. The challenge of innovation disunion: Nature-based solutions in Poland. In NatureBased Solutions to Climate Change Adaptation in Urban Areas: Linkages between Science, Policy and Practice; Kabisch, N., Korn, H., Stadler, J., Bonn, A., Eds.; Springer: Cham, Switzerland, 2017; pp. 291-305.

51. Albert, C.; Schröter, B.; Haase, D.; Brillinger, M.; Henze, J.; Herrmann, S.; Gottwald, S.; Guerrero, P.; Nicolas, C.; Matzdorf, B. Addressing societal challenges through nature-based solutions: How can landscape planning and governance research contribute? Landsc. Urban Plan. 2019, 182, 12-21. [CrossRef]

52. Santoro, S.; Pluchinotta, I.; Pagano, A.; Pengal, P.; Cokan, B.; Giordano, R. Assessing stakeholders' risk perception to promote Nature Based Solutions as flood protection strategies: The case of the Glinščica river (Slovenia). Sci. Total Environ. 2019, 655, 188-201. [CrossRef] [PubMed]

53. Chausson, A.; Turner, B.; Seddon, D.; Chabaneix, N.; Girardin, C.A.; Kapos, V.; Seddon, N. Mapping the effectiveness of nature-based solutions for climate change adaptation. Glob. Chang. Biol. 2020, 26, 6134-6155. [CrossRef] [PubMed]

54. Andersson, E.; Borgström, S.; McPhearson, T. Double insurance in dealing with extremes: Ecological and social factors for making nature-based solutions last. In Nature-Based Solutions to Climate Change Adaptation in Urban Areas: Linkages between Science, Policy and Practice; Kabisch, N., Korn, H., Stadler, J., Bonn, A., Eds.; Springer: Cham, Switzerland, 2017; pp. 51-64.

55. The 2030 Agenda for Sustainable Development. 2015. Available online: https: / / sustainabledevelopment.un.org/?menu=1300 (accessed on 12 January 2021).

56. Gough, M.Z.; Accordino, J. Public gardens as sustainable community development partners: Motivations, perceived benefits, and challenges. Urban Aff. Rev. 2013, 49, 851-887. [CrossRef]

57. Rowinski, R.; Morgulec-Adamowicz, N.; Ogonowska-Słodownik, A.; Dąbrowski, A.; Richley, G.P. Participation in leisure activities and tourism among older people with and without disabilities in Poland. Arch. Gerontol. Geriatr. 2017, 73, 82-88. [CrossRef] [PubMed]

58. Duś, E. Tendencje zmian w rolniczym użytkowaniu ogrodów działkowych w świetle zagrożeń ekologicznych. In Rolnictwo na Obszarach Wielofunkcyjnych; Materiały X Seminarium Geograficzno-Rolniczego: Kielce, Poland, 1993; pp. 35-41. (In Polish)

59. Duś, E. Przeszłość i współczesny stan ogrodnictwa działkowego w Chorzowie. Zesz. Chorzowskie 1997, 1, 135-151. (In Polish)

60. Escobedo, F.J.; Kroeger, T.; Wagner, J.E. Urban forests and pollution mitigation: Analyzing ecosystem services and disservices. Environ. Pollut. 2011, 159, 2078-2087. [CrossRef]

61. Nesbitt, L.; Hotte, N.; Barron, S.; Cowan, J.; Sheppard, S.R.J. The social and economic value of cultural ecosystem services provided by urban forests in North America: A review and suggestions for future research. Urban For. Urban Green. 2017, 25, 103-111. [CrossRef]

62. Referowska-Chodak, E. Management and social problems linked to the human use of European urban and suburban forests. Forests 2019, 10, 964. [CrossRef]

63. Haase, D.; Kabisch, N.; Haase, A. Endless urban growth? On the mismatch of population, household and urban land area growth and its effects on the urban debate. PLoS ONE 2013, 8, e66531. [CrossRef] [PubMed]

64. Hanson, H.I.; Wickenberg, B.; Olsson, J.A. Working on the boundaries-How do science use and interpret the nature-based solution concept? Land Use Policy 2020, 90, 104302. [CrossRef]

65. Lafortezza, R.; Chen, J.; Van den Bosch, C.; Randrup, T. Nature-based solutions for resilient landscapes and cities. Environ. Res. 2017, 165, 431-441. [CrossRef] [PubMed]

66. Langemeyer, J.; Camps-Calvet, M.; Calvet-Mir, L.; Barthel, S.; Gómez-Baggethun, E. Stewardship of urban ecosystem services: Understanding the value(s) of urban gardens in Barcelona. Landsc. Urban Plan. 2018, 170, 79-89. [CrossRef]

67. Le Guern, C.; Jean-Soro, L.; Béchet, B.; Lebeau, T.; Bouquet, D. Management initiatives in support of the soil quality of urban allotment gardens: Examples from Nantes (France). Land Degrad. Dev. 2018, 29, 3681-3692. [CrossRef] 